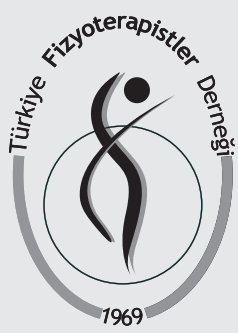

ISSN: $2651-4451 \cdot e-I S S N: 2651-446 X$

\section{Türk Fizyoterapi ve Rehabilitasyon Dergisi}

$201829(3) 53-58$

Meltem IŞINTAŞ ARIK, PhD, PT Hümeyra KILOATAR, MSc, PT Kevser ONBAŞI, MD²

\title{
RELATIONSHIP BETWEEN BALANCE AND FEAR OF FALLING IN GERIATRIC TYPE 2 DIABETES MELLITUS PATIENTS
}

\author{
ORIGINAL ARTICLE
}

\section{ABSTRACT}

Purpose: The purpose of this study was to compare balance parameters and fear of falling in geriatric individuals with and without type 2 diabetes mellitus (DM), and to investigate the relationship between balance and fear of falling in these groups.

Methods: The study included 31 type 2 DM patients who were diagnosed by a specialist and 29 age-matched controls. Fear of falling was assessed using the International Fall Efficacy Scale. The balance parameters including the center of the pressure (COP) which are the COP length and the COP velocity were measured and recorded using a gait analysis system, in standing position. The balance was also assessed using timed up and go test (TUG).

Results: There was a significant difference between diabetic and control groups regarding COP length $(p=0.021)$ and COP velocity $(p=0.028)$. In the diabetic patients, there was a statistically significant relationship between fear of falling and COP length $(p=0.001)$ and COP velocity $(p=0.001)$. There was a significant correlation between TUG and COP velocity $(p<0.001)$ and COP length $(p<0.001)$ in type 2 DM patients.

Conclusion: In elderly with type 2 DM, increased balance disturbances occurred compared to agematched individuals without DM, and fear of falling was associated with balance in geriatric type 2 DM patients. It is, therefore, vital to understand the changes occurring in balance so that future complications may be prevented, early diagnosis and intervention may be achieved in the event of a problem, and a decision about appropriate approaches for treatment can be made.

Key Words: Balance; Diabetes Mellitus; Fear; Accidental Falls.

\section{GERIATRIK TIP 2 DIYABETES MELLITUSU OLAN HASTALARDA DENGE PARAMETRELERI VE DÜŞME KORKUSUNUN íLişKISi}

1 Kütahya Health Sciences University, Faculty of Health Sciences, Department of Physiotherapy and Rehabilitation, Kütahya, Turkey.

2 Kütahya Health Sciences University, Faculty of Health Sciences, Department of Internal Medicine, Kütahya, Turkey.

Illetişim (Correspondence):

Hümeyra KILOATAR, MSc, PT Kutahya Health Sciences University, Department of Physiotherapy and Rehabilitation, Faculty of Health Sciences, Campus of Evliya Çelebi, 43100 Kütahya, Turkey Phone: +90-274-265 2031 ext. 3617 E-mail: humeyra.kiloatar@ksbu.edu.tr

Meltem IŞINTAŞ ARIK E-mail: meltem.iarik@ksbu.edu.tr

Kevser ONBAŞI

E-mail: kevser.onbasi@ksbu.edu.tr

Geliș Tarihi: 05.02.2018 (Received) Kabul Tarihi: 20.06.2018 (Accepted)

\section{ARAŞTIRMA MAKALESI}

\section{ÖZ}

Amaç: Bu çalışmanın amacı, tip 2 diyabeti olan ve olmayan geriatrik bireylerde denge parametreleri ve düşme korkusunu karşılaştırmak ve bu gruplarda denge parametreleri ve düşme korkusu arasındaki ilişkiyi incelemekti.

Yöntem: Çalışmaya, uzman hekim tarafından tip 2 diyabet tanısı konulmuş 31 hasta ve aynı yaş grubunda 29 kontrol grubu dahil edildi. Düşme korkusu Uluslararası Düşme Etkinlik Skalası ile değerlendirildi. Denge ile ilgili basınç merkezi (BM) uzunluğu ve BM hızı ayakta durma pozisyonunda, yürüme analiz sisteminde, Zebris FDM-2 cihazıyla kaydedildi. Katılımcıların dengesi aynı zamanda süreli kalk yürü testi (SKYT) ile değerlendirildi.

Sonuçlar: Diyabetli grup ve kontrol grubu arasında BM uzunluğu $(p=0,021)$ ve BM hızı $(p=0,028)$ açısından anlamlı bir fark bulundu. Diyabetli hastalarda düşme korkusu, BM hızı $(p=0,001)$ ve BM uzunluğu $(p=0,001)$ arasında istatistiksel olarak anlamlı bir ilişki bulundu. Diyabetli hastalarda SKYT, BM hızı $(p<0,001)$ ve BM uzunluğu $(p<0,001)$ arasında istatistiksel olarak anlamlı bir korelasyon bulundu.

Tartışma: Geriatrik tip 2 diyabetli kişilerde, aynı yaş aralığındaki kontrol grubu ile karşılaştırıldığında daha fazla denge bozukluğu görülmüş ve düşme korkusu tip 2 diyabetli kişilerde denge ile ilişkili bulunmuştur. Bu nedenle, dengede meydana gelen değişiklikleri anlamak önemlidir. Böylece diyabetik hastalarda ortaya çıkabilecek komplikasyonlar önlenebilir; sorun olması durumunda erken tanı ve müdahale sağlanabilir ve tedaviye yönelik uygun yaklaşımlar hakkında bir karar verilebilir.

Anahtar Kelimeler: Denge; Diyabetes Mellitus; Korku; Düşme. 


\section{INTRODUCTION}

Diabetes mellitus (DM) is a chronic disease that occurs when there are raised levels of glucose in the blood because the body cannot produce any or enough of the hormone insulin or use insulin effectively (1). Type 2 diabetes is the most common type of diabetes, accounting for around $90 \%$ of all cases of diabetes (2). Diabetes is a growing health problem. Some 425 million people worldwide, or $8.8 \%$ of adults aged between 20-79 years, are estimated to have diabetes. By year 2045, 629 million people aged between 20-79 years, will have diabetes (3). Diabetes indicates high prevalence in people older than 65 years. In 2017, it is estimated that the number of people with diabetes will be 122.8 million among the people aged between 65-99 years, and the prevalence will be $18.8 \%$ (3).

Healthy aging is associated with slower cognitive processing, slower postural reactions, and decreased muscle strength, all of which are associated with balance problems (4). This process is progressing rapidly in elderly with type 2 DM (4). Chronic microvascular complications of diabetes are nephropathy, neuropathy, and retinopathy which may cause some impairments including reduced balance (3). Performance of the balance system is commonly assessed in the laboratory by quantifying sway during quiet upright stance. The most commonly used measures of sway are various parameters derived from the center of pressure (COP) (5). The COP is defined as the point of application of the ground reaction forces under the feet (6). The COP path length and the mean $\mathrm{COP}$ velocity are the parameters derived from COP used to asses balance (7).

The FOF is described as ongoing concern about falling that ultimately limits the performance of daily activities by Tinetti and Powell (8). Another description has referred to FOF as a patient's loss of confidence in his or her balance abilities (9). Patients with DM may have balance problems and FOF (10). The FOF decreases willingness to mobility leading to decrease exercise and/or physical activity which are effective methods for controlling blood glucose. There is also a reduction in quality of life through muscle weakness, postural instability, and gait abnormalities, and an increase in the incidence of fall-related secondary injuries (11). Therefore, FOF and balance may affect each other. However, there is a lack of study evaluating the relationship between FOF and balance objectively in elderly with type $2 \mathrm{DM}$ in comparison with those without type $2 \mathrm{DM}$. The purpose of this study was to compare the balance parameters and FOF in geriatric individuals with and without type 2 diabetes, and to investigate the relationship between balance parameters and FOF in these groups.

\section{METHODS}

\section{Subjects}

Between April and August 2016, 31 patients with type 2 DM and 29 age-matched control group were included in the study. Diabetes group was composed of persons who were diagnosed as type $2 \mathrm{DM}$ by an endocrinologist, and the control group consisted of people who were not diagnosed as type 2 DM by the endocrinologist. The Ethics Board for Clinical Research at Dumlupinar University approved the study protocol (2016-5/14,04, 2016), and a written informed consent form was obtained from all participants. Subjects with type 2 DM were included in the study if they were over the age of 55 years and independently ambulatory without assistive devices (12). Subjects with type 2 DM were excluded if they had a history of severe neurological disease or orthopedic problem, foot ulcers, severe visual impairment, severe cardiovascular and respiratory diseases, active cancer, or peripheral neuropathy $(4,13)$. Control group was included if they were not diagnosed as type $2 \mathrm{DM}$ by the endocrinologist, and they were over the age of 55 years and independently ambulatory without assistive devices.

\section{Clinical Evaluation}

Study participants underwent a comprehensive assessment including age, gender, visual problems, falling history, and chronic diseases. The FOF was assessed using the International Falls Efficacy Scale (FES) $(14,15)$, which evaluates concerns about falling during 16 daily activities, scored from 1 (not at all concerned) to "somewhat" (2), "fairly" (3), and "very concerned" (4) yielding a maximum score of 64 (the higher the score, the worse the concern) (15). 
Table 1: Characteristics of the Subjects.

\begin{tabular}{|l|c|c|c|}
\hline Variables & $\begin{array}{c}\text { Diabetes } \\
(\mathbf{n = 3 1 )}\end{array}$ & $\begin{array}{c}\text { Control } \\
(\mathbf{n = 2 9 )}\end{array}$ \\
\hline Age (years) & $62.90 \pm 6.10$ & $60.93 \pm 5.25$ & $\mathbf{p}$ \\
\hline Height (cm) & $162.48 \pm 9.01$ & $164.17 \pm 9.84$ & 0.186 \\
\hline Weight (kg) & $84.60 \pm 16.30$ & $78.60 \pm 18.57$ & 0.232 \\
\hline BMI (kg/m $)$ & $31.82 \pm 5.60$ & $29.00 \pm 5.98$ & 0.065 \\
\hline TUG (sec) & $11.87 \pm 3.98$ & $9.31 \pm 2.17$ & $\mathbf{0 . 0 0 3}$ \\
\hline FES Score & $22.16 \pm 9.57$ & $20.62 \pm 6.17$ & 0.465 \\
\hline Chronic Diseases, $\mathbf{n}(\%)$ & $21(67.7)$ & $15(51.7)$ & 0.209 \\
\hline Fall History, $\mathbf{n}(\%)$ & $4(12.9)$ & $7(24.1)$ & 0.265 \\
\hline Visual Problems, $\mathbf{n}(\%)$ & $18(58.1)$ & $23(79.3)$ & 0.080 \\
\hline
\end{tabular}

${ }^{*} \mathrm{p}<0.05$. Data are shown as Mean \pm standard deviation or frequency and percentage. BMI: body mass index, TUG: Timed Up and Go test, FES: Fall Efficacy Scale.

\section{Balance Evaluation}

The balance was assessed using the timed up and go test (TUG) (16). The starting position of the test was standardized. The test was initiated at the position where the patient's feet were flat on the floor with arms positioned on the armrest of the seat. The TUG measures the time in seconds with a chronometer: the time it takes to stand up from a chair, walk 2.8 feet, turn around, walk back, and sit down. The best of three trials was used in the analysis. Shorter time shows better balance and mobility (17).

Balance parameters were recorded using gait analysis system (Zebris ${ }^{\text {TM }}$ FDM-2, Zebris Medical $\mathrm{GmbH}$, Germany). The Zebris FDM-2 is a device used in gait and balance assessment that has a frequency range of $120 \mathrm{~Hz}$, a length of $2122 \mathrm{~cm}$, a width of $605 \mathrm{~mm}$, and a height of $21 \mathrm{~mm}$, and 15360 sensors. The measuring plates enable the static and dynamic force distribution to be analyzed under the feet while standing and walking. When analyzing stance, the left/right load, as well as the fore and back foot are displayed as a numeric value and in a bar chart. The line connecting the main points of the body provides immediate information on asymmetrical load distribution. The measured data were recorded over a defined period, in which the results were averaged. The data obtained from the device were recorded in a report via Zebris software installed on the computer (18).

The participants were instructed to remain in an orthostatic position with an unrestricted base that brought comfort, with no movements of the upper limbs and maintaining the eyes on a target attached to the wall at a distance of $1 \mathrm{~m}$ from the platform at eye level. The participants performed the test barefoot, with eyes open. Each data collection time was 30 seconds (19). The COP parameters assessed in this study were COP velocity $(\mathrm{cm} /$ $\mathrm{sec}$ ) and COP length $(\mathrm{cm})$. An increase in COP velocity is thought to represent a decreased ability to control posture whereas a decrease in the velocity represents an increase in the ability to maintain an upright stance (20). The path length of the COP serves as a valid outcome measure in diverse populations and balance conditions (21).

\section{Statistical Analysis}

The Statistical Package for the Social Sciences, Version 13 for Windows (SPSS, Inc., Chicago, IL, USA) was used to conduct the statistical analysis. The Kolmogorov-Smirnov Test was used to analyze the normal distribution of the parameters. Parametric tests were applied because the parameters were normally distributed. The Student t test was

Table 2: Comparison of Center of Pressure Parameters of the Diabetic and Control Groups.

\begin{tabular}{|l|c|c|c|c|}
\hline COP Parameters & $\begin{array}{c}\text { Control }(\mathbf{n}=\mathbf{2 9}) \\
(\text { Mean } \pm \text { SD) }\end{array}$ & $\begin{array}{c}\text { Diabetic }(\mathbf{n}=\mathbf{3 1}) \\
(\text { Mean } \pm \text { SD) }\end{array}$ & p & Cohen's d \\
\hline Length $(\mathbf{c m})$ & $240.75 \pm 109.40$ & $350.41 \pm 224.81$ & $\mathbf{0 . 0 2 1}^{*}$ & 0.62 \\
\hline Velocity $(\mathbf{c m} / \mathbf{s e c})$ & $8.34 \pm 3.82$ & $11.96 \pm 7.82$ & $\mathbf{0 . 0 2 8 ^ { * }}$ & 0.58 \\
\hline
\end{tabular}

${ }^{*} \mathrm{p}<0.05$. COP: Center of Pressure. 
Table 3: The Relationship between Fear of Falling, Timed Up and Go Test, and Center of Pressure Parameters in Diabetes and Control Groups.

\begin{tabular}{|c|c|c|c|}
\hline Test & Groups & COP Length $(\mathrm{cm})$ & COP Velocity $(\mathrm{cm} / \mathrm{sec})$ \\
\hline \multirow{2}{*}{ FOF } & Diabetes $(n=31)$ & $\begin{array}{c}r=0.546 \\
p=0.001\end{array}$ & $\begin{array}{c}r=0.556 \\
\mathbf{p}=\mathbf{0 . 0 0 1}\end{array}$ \\
\hline & Control $(n=29)$ & $\begin{array}{l}r=0.292 \\
p=0.125\end{array}$ & $\begin{array}{l}r=0.281 \\
p=0.140\end{array}$ \\
\hline \multirow{2}{*}{ TUG } & Diabetes $(n=31)$ & $\begin{array}{c}r=0.758 \\
p=0.001 *\end{array}$ & $\begin{array}{c}r=0.763 \\
\mathbf{p}=\mathbf{0 . 0 0 1}\end{array}$ \\
\hline & Control (n=29) & $\begin{array}{l}r=0.220 \\
p=0.253\end{array}$ & $\begin{array}{l}r=0.210 \\
p=0.275\end{array}$ \\
\hline
\end{tabular}

${ }^{*} \mathrm{p}<0.01$, r: Pearson's correlation test, COP: Center of Pressure, FOF: Fear of Falling, TUG: Timed Up and Go.

used for testing the significance of the difference between the mean difference in the two groups. In both the diabetic and control groups, the relationship between COP and FOF and TUG parameters was analyzed using Pearson's correlation test. Correlation coefficients was interpreted as in Pearson's correlation test; $0.00-0.19$ no relationship, 0.20-0.39 weak relationship, 0.40-0.69 moderate relationship, $0.70-0.89$ strong relationship, and 0.90-1.00 very strong relationship (22). The effect size of differences in COP parameters in the diabetes group and the control group was assessed. If Cohen's $d$ value is less than 0.2 , the effect size is weak, if it is 0.5 , it is medium, and if it is larger than 0.8 , it is defined as strong (22). A significance level of $p<0.05$ was determined.

\section{RESULTS}

Clinical variables and demographic information are given in Table 1. No significant difference was found regarding age, height, weight, BMI, presence of chronic disease, visual impairment, and fall history between patients and controls $(p>0.05)$. The duration of diabetes in patients was $11.17 \pm 7.64$ (0.50-28) years. There was no statistical difference in FOF between patients and controls $(p=0.465)$. A statistically significant difference was found between the two groups in the TUG test $(p=0.003)$ (Table 1).

There was a significant difference between diabetic and control groups regarding COP parameters $(p=0.021, p=0.028)$ (Table 2$)$. In the diabetic group, there was a moderate correlation between COP length and velocity and FOF ( $r=0.546, p=0.001$ and $r=0.556, p=0.001$ ). In the control group, there was no relationship between COP parameters and FOF ( $p>0.05$ ) (Table 3). There was a strong correla- tion between COP velocity, COP length, and TUG $(r=0.758, p=0.001$ and $r=0.763, r=0.001)$. In the control group, there was no relationship between COP parameters and TUG ( $p>0.05$ ) (Table 3).

\section{DISCUSSION}

The current study was the first to investigate the FOF and COP based findings of balance in elderly with type $2 \mathrm{DM}$ and age-gender matched controls. This study showed that there was a relationship between FOF, COP length, and COP velocity in elderly with type $2 \mathrm{DM}$ but there was no relationship in the controls.

Balance is commonly assessed in the laboratory using quantifying sway during upright stance. The most commonly used measures of sway are various parameters derived from temporal patterns of COP (23). The COP is calculated from ground-reaction forces. It reflects the path of the center of mass and the amount of torque applied to the support surface to control body-mass acceleration (24). Several studies have shown the reliability of COP parameters during quiet standing in the elderly (23). However, there is no study published about COP parameters in elderly diabetic patients.

The COP velocity has been used to assess changes in COP (25). An increase in COP velocity is thought to represent a decreased ability to control posture, whereas a decrease in the velocity represents an increase in the ability to maintain an upright stance (20). In this study, COP velocity was higher in diabetic group compared to control group. According to our results, higher COP velocity may reflect the worse balance in type 2 DM patients. The path length of the COP serves as a valid outcome measure in diverse populations and balance conditions (21). In the current study, COP length 
was longer in diabetic group compared to control group. Increased COP length may be an adaptation for maintaining balance control. Whereas FOF affected COP length in diabetic patients, it did not affect in controls. Tander et al. showed that diabetic patients have more balance disturbances compared to age-matched individuals without DM (10). Whereas FOF affected COP velocity in diabetic patients probably due to a lower FOF in control groups compared to diabetic clinically. Elderly with low levels of FOF use an adaptation mechanism optimizing balance, rather than showing decreased balance control (26). Findings of Reelick et al. supported our results. They found that in healthy elderly population, FOF did not influence balance parameters (26). Some studies showed that FOF affected balance in people with diabetes $(10,27)$ using Berg Balance Scale for assessing balance. In our study, we used force platform for assessing balance. This method is more objective than clinical scales (23).

The TUG test is an important clinical test for assessing balance, mobility, and risk of fall. Similar to our findings, some studies showed that TUG time was longer in elderly diabetics compared to healthy individuals $(28,29)$. The TUG significantly correlated COP length and COP velocity. If there is a lack of force platform or gait analysis system to assess balance, TUG test may be used reliably in the daily clinical practice.

One of the limitations of our study was that many factors can affect balance in patients with type 2 diabetes. Nevertheless, our study is clinically relevant because FOF is one of the factors affecting balance, and our study showed that FOF has an adverse effect on balance.

In conclusion, our study showed that in elderly with Type 2 DM had more balance disturbances compared to age-matched individuals without DM. While there was no significant difference regarding FOF between diabetics and controls, FOF affected negatively balance in diabetic patients. The TUG correlated COP length and COP velocity. The COP parameters may be used reliably for assessing balance in the daily clinical practice. It is, therefore, vital to understand the changes that occur in balance so that possible complications in diabetic patients may be prevented, early diagnosis and intervention may be achieved in the event of a problem, and a decision about appropriate approaches for treatment could be made. For further study, the recommendation would be that studies are undertaken to explore the short and long-term effects of balance training and fear of falling should be taken into account in geriatric Type 2 DM patients.

\section{Sources of Support: None.}

Conflict of Interest: The authors declare no conflict of interest.

Ethical Approval: The study protocol was accepted by the Ethics Board for Clinical Research at Dumlupinar University (2016-5/14,04,2016).

Informed Consent: A written informed consent form was obtained from all participants.

Acknowledgements: None.

\section{REFERENCES}

1. DeFronzo RA, Ferrannini E, Zimmet P, Alberti G. International textbook of diabetes mellitus. 2 Volume Set. 4th ed. Chichester: John Wiley \& Sons; 2015.

2. Shah AD, Langenberg C, Rapsomaniki E, Denaxas S, Pujades-Rodriguez M, Gale CP, et al. Type 2 diabetes and incidence of a wide range of cardiovascular diseases: a cohort study in 1.9 million people. Lancet Diabetes Endocrinol. 2015;385(suppl 1):S86

3. International Diabetes Federation. IDF Diabetes Atlas, 7th ed. Brussels, Belgium: International Diabetes Federation; 2015.

4. Morrison S, Colberg SR, Mariano M, Parson HK, Vinik Al. Balance training reduces falls risk in older individuals with type 2 diabetes. Diabetes Care. 2010;33(4):748-50.

5. Baloh RW, Fife TD, Zwerling L, Socotch T, Jacobson K, Bell T, et al. Comparison of static and dynamic posturography in young and older normal people. J Am Geriatr Soc. 1994;42(4):405-12.

6. Winter DA. Human balance and posture control during standing and walking. Gait Posture. 1995;3(4):193-214.

7. Donath L, Roth R, Zahner L, Faude O. Testing single and double limb standing balance performance: comparison of COP path length evaluation between two devices. Gait Posture. 2012;36(3):439-43.

8. Tinetti ME, Powell L. Fear of falling and low self-efficacy: a case of dependence in elderly persons. J Gerontol. 1993;48(Spec Issue):35-8.

9. Maki BE, Holliday PJ, Topper AK. Fear of falling and postural performance in the elderly. J Gerontol. 1991;46(4):M123-31.

10. Tander B, Atmaca A, Ulus Y, Tura Ç, Akyol Y, Kuru Ö. Balance performance and fear of falling in older patients with diabetics: a comparative study with non-diabetic elderly. Turk J Phys Med Rehab. 2016;62(4):314-22.

11. Lim K-B, Kim DJ, Noh J-H, Yoo J, Moon J-W. Comparison of balance ability between patients with Type 2 diabetes and with and without peripheral neuropathy. PM\&R. 2014;6(3):209-14.

12. Corriveau H, Prince F, Hebert R, Raiche M, Tessier D, Maheux P, et al. Evaluation of postural stability in elderly with diabetic neuropathy. Diabetes Care. 2000;23(8):1187-91

13. Allet L, Armand S, de Bie RA, Golay A, Monnin D, Aminian K, et al. The gait and balance of patients with diabetes can be improved: a randomised controlled trial. Diabetologia. 2010;53(3):458-66.

14. Yardley L, Beyer N, Hauer K, Kempen G, Piot-Ziegler C, Todd C. Development and initial validation of the Falls Efficacy Scale-International (FES-I). Age Ageing. 2005;34(6):614-9.

15. Ulus Y, Durmus D, Akyol Y, Terzi Y, Bilgici A, Kuru O. Reliability and va- 
lidity of the Turkish version of the Falls Efficacy Scale International (FES-I) in community-dwelling older persons. Arch Gerontol Geriatr. 2012;54(3):429-33.

16. Podsiadlo D, Richardson S. The timed "Up \& Go": a test of basic functional mobility for frail elderly persons. J Am Geriatr Soc. 1991:39(2):142-8.

17. Bischoff HA, Stahelin HB, Monsch AU, Iversen MD, Weyh A, von Dechend $\mathrm{M}$, et al. Identifying a cut-off point for normal mobility: a comparison of the timed 'up and go' test in community-dwelling and institutionalised elderly women. Age Ageing. 2003;32(3):315-20.

18. Suciu O, Onofrei RR, Totorean AD, Suciu SC, Amaricai EC. Gait analysis and functional outcomes after twelve-week rehabilitation in patients with surgically treated ankle fractures. Gait Posture. 2016;49:184-9.

19. Anjos DMC, Gomes LPO, Sampaio LMM, Correa JCF, Oliveira CS. Assessment of plantar pressure and balance in patients with diabetes. Arch Med Sci. 2010;6(1):43-8.

20. Le Clair K, Riach C. Postural stability measures: what to measure and for how long. Clin Biomech. 1996;11(3):176-8

21. Jakobsen MD, Sundstrup E, Krustrup P, Aagaard P. The effect of recreational soccer training and running on postural balance in untrained men. Eur J Appl Physiol. 2011;111(3):521-30.

22. Alpar R. Uygulamalı istatistik ve geçerlik-güvenirlik: spor, sağılık ve eğitim bilimlerinden örneklerle. Ankara: Detay Yayıncılık; 2010.
23. Lin D, Seol H, Nussbaum MA, Madigan ML. Reliability of COP-based postural sway measures and age-related differences. Gait Posture. 2008;28(2):337-42.

24. Winter DA, Patla AE, Frank JS. Assessment of balance control in humans. Med Prog Technol. 1990;16(1-2):31-51.

25. Baloh RW, Jacobson KM, Enrietto JA, Corona S, Honrubia V. Balance disorders in older persons: quantification with posturography. Otolaryngol Head Neck Surg. 1998;119(1):89-92.

26. Reelick MF, van lersel MB, Kessels RP, Rikkert MG. The influence of fear of falling on gait and balance in older people. Age Ageing. 2009;38(4):435-40.

27. Moreira Bde S, Dos Anjos DM, Pereira DS, Sampaio RF, Pereira LS, Dias RC, et al. The geriatric depression scale and the timed up and go test predict fear of falling in community-dwelling elderly women with type 2 diabetes mellitus: a cross-sectional study. BMC Geriatr. 2016;16(1):56

28. Chiba Y, Kimbara Y, Kodera R, Tsuboi Y, Sato K, Tamura Y, et al. Risk factors associated with falls in elderly patients with type 2 diabetes. J Diabetes Complicat. 2015;29(7):898-902.

29. Kukidome D, Nishikawa T, Sato M, Nishi Y, Shimamura R, Kawashima J, et al. Impaired balance is related to the progression of diabetic complications in both young and older adults. J Diabetes Complicat. 2017;31(8):1275-82. 